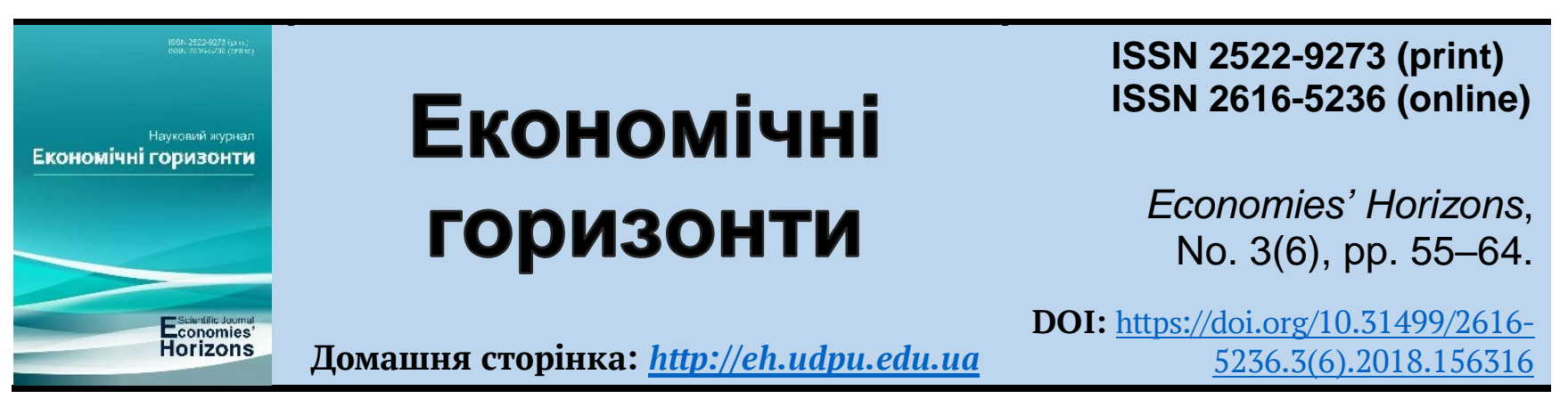

JEL Classification: G 22, K 30

\title{
Organizational and legal bases of life insurance provision in Ukraine
}

\author{
Yuliia M. Melnychuk ${ }^{1}$, Cand. Ec. Sc. \\ Maksym A. Slatvinskyi ${ }^{2}$, Cand. Ec. Sc., Associate Professor
}

Received: 07 September 2018

Melnychuk, Yu. M. and Slatvinskyi, M. A. (2018), "Organizational and legal bases of life insurance provision in Ukraine", Economies' Horizons, No.3(6), pp. 55-64, doi: https://doi.org/10.31499/2616-5236.3(6).2018.156316.

Accepted: 21 September 2018

Abstract. The article reveals the legal bases and organizational directions of life insurance companies. The purpose of the study is to identify the main legal and organizational foundations for life insurance. Methodology. The totality of research methods is a methodology for analyzing and organizing the main legislative acts and laws, namely the methods of generalization, comparison, chronology, analysis and generalization. Results. The legislation on life insurance pays much attention to the organizational aspect of the establishment and operation of insurers, but the implementation of the law does not reflect the state and reliability of the life insurance company, nor does it affect the choice of the company in which a person wants to insure his life. In article characterized the legislative basis, a chronological description of the historical development and establishment of insurance in Ukraine. Comparison and analysis of insurance contracts were conducted. Conclusions are made on changes in the organizational and legal principles of life insurance in order to improve it. Practical meaning. The results of the study can be used in the practice of insurers for life insurance to self-check compliance with the legislative and legal framework for the organization of insurance activities. Prospects for further research. On the basis of the research carried out, there is an objective need to find out the theoretical and methodological foundations of the insurance companies' activity for making decisions on life insurance.

Keywords: legal foundations, insurance, life insurance, insurance contract, insurance system, insurance programs.

\footnotetext{
${ }_{1}$ Pavlo Tychyna Uman State Pedagogical University; Associate Professor at the Department of Finance, Accounting and Economic Security; ORCID ID: https://orcid.org/0000-0003-4149-0205; e-mail: melnichykyuliya@ukr.net.

${ }^{2}$ Pavlo Tychyna Uman State Pedagogical University; Head of the Department of Finance, Accounting and Economic Security; ORCID ID: http://orcid.org/0000-0003-4096-2901; e-mail: sl.m@ukr.net.
} 
УДК 368.91

\title{
Організаційні та правові засади страхування життя в Україні
}

\author{
Ю. М. Мельничук ${ }^{1}$, к. е. н.
}

М. А. Слатвінський ${ }^{2}$, к. е. н., доцент

Стаття надійшла: 07.09.2018

Стаття прийнята: 21.09.2018

Melnychuk Yu. M., Slatvinskyi M. A. Organizational and legal bases of life insurance provision in Ukraine. Економічні горизонти. 2018. № 3(6). С. 55-64. DOI: $10.31499 / 2616-5236.3(6) \cdot 2018.156316$.

Анотація. Стаття спрямована на аналіз основних законодавчих актів щодо становлення та розвитку страхування життя в Україні. Ринок страхування життя в кожній країні $є$ індикатором економіки та сталого розвитку підприємництва. Стрімке старіння населення всіх країн світу виснажує фінансову спроможність громадян, що призводить до низького рівня охорони здоров'я та пенсійного забезпечення. 3 отриманням незалежності, в Україні відбувається постійний розвиток законодавчого, державного регулювання ринку страхування життя. Визначено, що для цього було прийнято ряд законів, указів та проектів, що сприяють поліпшенню страхового ринку та умов функціонування страховиків. Зазначено, що законодавство про страхування життя багато уваги приділяє організаційному та правовому аспекту створення та функціонування страховиків, тому, виникає об'єктивна необхідність 3'ясування організаційно-правових засад діяльності компаній для прийняття рішень щодо страхування життя. Метою дослідження є виявлення основних правових та організаційних засад становлення страхування життя. Методологія. Сукупність методів дослідження становить методологію аналізу та організації основних законодавчих актів та законів, а саме методи узагальнення, порівняння, хронологізації, аналізу та узагальнення. Результати. Законодавство про страхування життя приділяє велику увагу організаційному аспекту створення та діяльності страховиків, проте реалізація умов закону не може відображати стан та надійність компанії зі страхування життя, а також не впливає на вибір компанія, в якій людина хоче застрахувати життя. У статті розкрито правові основи та організаційні напрями діяльності компаній зі страхування життя. Охарактеризовано законодавчу базу, хронологічний опис історичного розвитку та становлення страхування в Україні. Здійснено порівняння та аналіз договорів страхування. Зроблено висновок про зміни організаційноправових принципів страхування життя 3 метою його поліпшення. Зроблено висновок, що страхування життя дає змогу забезпечити щоденний захист людини - як сьогодні, так і в майбутньому. Це призводить до виникнення двох ефектів - у держави з'являються додаткові довгострокові кошти, які забезпечують фінансування інвестиційних проектів, що сприяє подальшому розвитку економіки країни; громадяни отримують страховий захист, накопичення на майбутні періоди, а відтак - захист інтересів людини. Практичне значення. Результати дослідження можна використовувати у практичній діяльності страховиків з страхування життя для самоперевірки дотримання законодавчої та правової бази при організації страхової діяльності. Перспективи подальших досліджень. На основі проведених досліджень виникає об'єктивна необхідність з'ясувати теоретичні та методологічні основи діяльності страхових компаній для прийняття рішень щодо страхування життя.

Ключові слова: правові основи, страхування, страхування життя, страховий договір, страхова система, програми страхування.

\footnotetext{
${ }^{1}$ Уманський державний педагогічний університет імені Павла Тичини; доцент кафедри фінансів, обліку та економічної безпеки; ідентифікатор ORCID: https://orcid.org/0000-0003-4149-0205; e-mail: melnichyk_yuliya@ukr.net.

${ }^{2}$ Уманський держсавний педагогічний університет імені Павла Тичини; завідувая кафедри фінансів, обліку та економічної безпеки; ідентифікатор ORCID: http://orcid.org/0000-0003-4096-2901; e-mail: sl.m@ukr.net.
} 


\section{Introduction.}

When stability and welfare of the country reaches a certain level, both workers and employers begin to think about their future, provide their old age, finance the risks that exist in every person's life. The basis for the implementation of insurance activities is the legal framework and the elements of its organization. An important scientific approach to the analysis of insurance activity is an analysis of the development of legislation on life insurance in Ukraine. Without studying organizational and legal provision it is impossible to give an objective characterization of insurance in general.

\section{Literature review.}

This problem is being studied by scientists, such as: L. Chvertko and T. Demchenko (2018), Yu. Melnychuk (2018), J. Burling (2017), S. Dominique-Ferreira (2017), V. Vuuren and A. Justine (2017), T. Shauhin (2017), K. Reznichenko (2015), I. Samofat (2015), G. Podolak (2015), M. Larsson (2015), M. Lönnborg (2015), M. Dubyna (2014), S. Zadorozhny (2014), A. Ishchenko (2014), N. Yaremenko (2013), A. Tkachenko (2013), K. Shmatko (2013) and others. At the same time, the issue of organizational and legal provision of insurance activity requires further research.

\section{Methodology.}

The totality of research methods is a methodology for analyzing and organizing the main legislative acts and laws, namely the methods of generalization, comparison, chronology, analysis and generalization.

\section{Research objectives.}

The purpose of the article is to study the peculiarities of the organizational and legal provision of insurance companies, analyze and identify problems and ways to improve the legal framework of insurance companies in Ukraine.

\section{Results and discussions.}

The explanatory note to the accounting report of the Organization of Ukrainian State Insurance for 1991 states: "The overwhelming part of the reserve of contributions in the amount of 3.8 billion rubles, representing 59\% of its total volume over the past 20 years, has been transferred to the Union budget" (Accounting Chamber of Ukraine, 2004). Consequently, in the presence of Organization of Ukrainian State Insurance should have remained insurance reserves in the amount of 2,6 billion Soviet rubles, paid by Ukrainian citizens.

"Oranta" Incorporated - the legal successor of the property rights and obligations of Organization of Ukrainian State Insurance. Together they for the period of 1993-1995 turned to various higher organizations of Ukraine and Russia for the return of funds under long-term life insurance contracts to Ukrainian insurers. Unfortunately, only depreciated compensatory savings in the amount of UAH 50 were made during 1997-1999. With such indicators the formation of life insurance in Ukraine began.

On May 10, 1993, the Cabinet of Ministers of Ukraine adopted the Decree "On Insurance”, which provided for the formation of insurance reserves for life insurance under the general conditions. This act did not take into account the peculiarities of life insurance, did not mention the list of insurance cases, did not indicate the mechanism of placement of insurance reserves for providing future payments, which led to significant problems in the field of life insurance and all possible maneuvers in order to reduce taxation, which resulted in operations not life insurance.

The first step that contributed to the development of life insurance in Ukraine was the adoption of the Law of Ukraine "On Insurance" dated March 7, 1996, which eliminated the deficiencies of the Decree "On Insurance". The first manifestation of understanding the peculiarities of life insurance by legislators was the prohibition of insurers from life insurance to carry out other types of insurance, other than life insurance. Ukrainian Insurance Supervision in June 1997 approved the Methodology for the formation of life insurance reserves. 
The basic development of the life insurance market begins with the adoption of the Law of Ukraine "On Insurance" dated October 4,2001 . The law defined the concept of "insurance secret", "life insurance contract", establishes requirements for such insurance, and also specifies the minimum size of the insurer's statutory fund, which deals with life insurance. The given law gives all opportunities for foreigners to carry out life insurance in Ukraine, which creates a healthy competitive environment in the insurance market, attracts foreign capital into the Ukrainian economy. On the basis of such laws, in 1998 the Austrian life insurance company "Grave Ukraine" commenced its activities. The beginning of the $21 \mathrm{st}$ century is reflected in the active restoration of the Ukrainian insurance market. It was at that time that insurance companies were set up such as Blue Polis, ASKA-Life, Garant-LIFE, Etalon Life, Illichivsk, Lemma-Vite, TAS with ukrainian and ukrainian-foreign capital and with the participation of foreign capital: Grave Ukraine, ALIKO AIG Life (for today it is MET-life Ukraine), Jupiter and others. Domestic insurers have been insuring long-term and short-term life insurance, providing other insurance services, and foreign companies long-term life insurance.

Unlike general insurance, long-term life insurance (more than 3 years) may well be designed to enrich the insured, namely, Article 9 of the Law of Ukraine "On Insurance" dated October 4, 2001, provides for the possibility of obtaining part (85\%) of the investment income of the insurer from placement of insurance reserves.

Article 12 The Law of Ukraine "On Financial Services and State Regulation of Financial Services Markets" no. 2664-III dated July 12, 2001 (The Verkhovna Rada of Ukraine, 2001) discloses the right of access to information on the activities of an insurer, which, at the request of a client company, must provide information on the following:

- information about financial indicators and economic status that are subject to mandatory disclosure;
- list of management of the company;

- list of services provided;

- tariffs for services;

- number of shares of the insurer, owned by members of the executive body, the list of persons whose shares in the authorized capital exceed $5 \%$.

Contribution to life insurance regulation was introduced by Directive 02/83 / EU of the European Parliament and the Council of the "Life Insurance" of November 5, 2002 (Official Journal, 2002), which recommends that under the life insurance contracts, the guaranteed investment income is not more than $4 \%$. Article 9 of the Law of Ukraine "On Insurance" establishes the same norm.

Legally established minimum statutory fund for life insurance companies in the amount equivalent to 1,5 million euros, at the exchange rate of Ukraine, paid exclusively in cash. At the same time, the legislation imposes restrictions:

- the formation of an authorized fund of an insurer by securities issued by the state is allowed at their nominal value in the order determined by the Financial Services Commission, but not more than $25 \%$ of the total authorized capital stock;

- it is forbidden to use promissory notes, funds of insurance reserves, budget funds received in loans, loans and collateral for the formation of the authorized fund, and to make intangible assets.

Five years after Ukraine's accession to the WTO, the minimum statutory fund of a life insurance company will amount to 10 million euros at the exchange rate of Ukraine (The Verkhovna Rada of Ukraine, 2005).

The total amount of contributions from a life insurance company to statutory funds of other insurers of Ukraine can not exceed 30\% of its own authorized capital, including the amount of contribution to the statutory fund of a separate insurer can not exceed 10\% (Zaletov, 2006, p. 283).

The insurer has the right to start insurance activity if (Table 1 ): 
Table 1. Legal regulation of the creation of an insurance life insurance company

\begin{tabular}{|l|l|}
\hline \multicolumn{1}{|c|}{ Indicator } & \multicolumn{1}{c|}{ Description of the indicator } \\
\hline 1. Registration system & $\begin{array}{l}\text { The registration system meets the requirements set by the regu- } \\
\text { latory acts }\end{array}$ \\
\hline 2. Internal rules & $\begin{array}{l}\text { The internal rules of the insurer comply with the requirements } \\
\text { of the laws of Ukraine and regulatory legal acts of state bodies } \\
\text { that regulate and oversee financial services markets }\end{array}$ \\
\hline $\begin{array}{l}\text { 3. Professional qualities } \\
\text { and reputation }\end{array}$ & $\begin{array}{l}\text { The professional qualities and business reputation of the per- } \\
\text { sonnel correspond to the requirements established by normative } \\
\text { and legal acts }\end{array}$ \\
\hline
\end{tabular}

Source: Formed by authors on the basis The Law of Ukraine "On Insurance" (The Verkhovna Rada of Ukraine, 2001).

The Law of Ukraine "On Amendments to the Law of Ukraine "On Insurance" no. 2774IV dated July 7, (The Verkhovna Rada of Ukraine, 2005), which takes effect five years after the accession of Ukraine to the WTO, it is determined that the insurers who have the right to exercise insurance activities in the territory of Ukraine, registered in accordance with the legislation of Ukraine, permanent representative offices in the form of branches of foreign insurance companies that have received a license for the insurance activity in accordance with the established procedure.

To ensure the solvency, financial stability and reliability of the insurer, the obligatory condition of its activity is:

- availability of paid-in share capital (EUR 1 million and EUR 1,5 million);

- availability of a guarantee fund, which consists of special funds, reserve funds, retained earnings;

- creation of insurance reserves sufficient for future insurance payments; profit;

- availability of free reserves created by

- exceeding the actual insolvency of the insurer over the estimated regulatory stock (Alexandrova, 2002, p. 85).

Formation of the authorized capital is not possible at the expense of loans, funds received on bail, insurance reserves, bills of exchange.

The main purpose of the insurance company is to maintain and increase capital in reverse-cumulation programs, as well as support for survivors of invalidity or death. Insurance programs can also be seen as "the possibility of creating a retirement capital or another source of permanent income" - says American scientist R. Dilendorf (Dilendorf, 2018, p. 50). One has to agree that at the expense of increased capital, that is, profits, the company not only provides solvency for insurance indemnity, but also provides reliability and competitiveness of its company.

The law pays special attention to ensuring the solvency of the insurer and clearly regulates the conditions for the creation of funds and reserves to ensure an adequate level of actual solvency margin of the life insurance company.

To provide life insurance liabilities, the company creates separate reserves at the expense of insurance payments and income from investing funds of such a reserve. Since the life insurance reserves are not property of the insurer, they must be separated from other property of the insurance company. Also, according to the legislation, such means of life insurance reserves can not be used by the insurer to repay any obligations other than those corresponding to the obligations under life insurance contracts and also can not be included in the liquidation mass in the event of insolvency of the insurer, and accordingly they are subject to transfer to another insurer, with the consent of the insured and the insured person, or the issue of the corresponding amount to the insured person. 
Lending to individuals who have entered into life insurance contracts is possible within the limits of the redemption amount at the time of the loan and on the security of the redemption amount. The loan can not be issued earlier than one year after the entry into force of the insurance contract and for a period exceeding the period remaining until the expiration of the insurance contract.

Life insurance reserves can be used for long-term lending to housing construction, including individual developers, in accordance with the procedure established by the Cabinet of Ministers of Ukraine. Legislation prohibits insurers from other types of credit activity.

In order to protect insurers from the failure of the insurer to fulfill their obligations, state control over investment activity is established. The European Union Directives establish the size of the volume of investment of insurance reserves, namely (The Verkhovna Rada of Ukraine, 2001):

- investment in real estate - no more than $10 \%$ of the total amount of reserves for each object;

- investments in shares, which are quoted and guaranteed loans - no more than $10 \%$ of the amount of reserves for each of these types of deposits;

- investments in unsecured loans - no more than $5 \%$ for each type of loan;

- in non-quoted shares - no more than $10 \%$ in the aggregate of investments;

- in cash - no more than $3 \%$ of the total reserves.

When entering into a long-term life insurance contract, the client pays annually to the company a specified amount of contributions. After the expiration of the contract, he can receive not only accumulated funds, but also multiply their money. Since, according to the law, life insurance companies must pay annually investment returns or bonuses on the insurer's funds, investing reserves and earning additional income, the amount of investment income stated in the life insurance contract must not exceed four percent per annum.
Life insurance contracts necessarily expected to increase the size of the sum insured and (or) of the amount of insurance payments (bonuses) are determined by the insurer once a year on the results obtained investment income from investment of funds of life insurance reserves, net of expenses insurer doing business in the amount of up to 15 percent of the received investment income, as well as the mandatory deduction to the mathematical reserves of the share of investment income, which corresponds to the amount of investment income, which correlated for calculating the insurance rate for this insurance agreement and, if indexed sum insured and (or) amount of insurance payments on the official inflation rate, contributions to mathematical reserves share of investment income that meets the following indexing (The Verkhovna Rada of Ukraine, 2001).

The funds of the insurance company involved in the circulation of funds can be divided into their own and involved. These funds are the insurer's financial resources. The financial resources of the insurance company are the cash receipts and receipts that are at the disposal of the latter for the performance of direct insurance and reinsurance operations from the moment of conclusion of the relevant agreement to the implementation of obligations in the form of payments of insurance and reimbursement, as well as for other expenses which provide the process of insurance, economic incentives for employees, costs, aimed at improving, improving the quality of insurance services provided.

An important contribution to the development of life insurance is the regulation of issues of state control over this kind of activity that took place with the adoption of the Law of Ukraine "On Financial Services and State Regulation of Financial Services Markets" and the Decree of the President of Ukraine no. 11553/2002 dated 11.12.2002. According to the law, the state policy of life insurance development in Ukraine is part of the overall socio-economic policy. The authorized state 
body of executive power in the field of insurance is the State Commission for Regulation of Financial Services Markets of Ukraine (Financial Services Commission) (The Verkhovna Rada of Ukraine, 2002). In accordance with the Law of Ukraine "On Amendments to the Law of Ukraine "On State Regulation of the Securities Market in Ukraine" dated 07.07.2011 No. 3610-VI, the State Commission for Securities and Stock Market was named the National Commission for Securities and Stock Market.

According to Article 41 of the Law of Ukraine "On Insurance", if the insurer is not responsible for obligations of the state, and the state - on the obligations of the insurer. Any centralized regulation (unification, restriction, binding, etc.) of insurance premiums (tariffs) and insurance amounts (insurance compensation), terms of conclusion of insurance contracts, interrelations between the insurer and the insured, if they do not contradict the legislation of Ukraine, except for obligatory types of insurance, life insurance, property of individuals, reinsurance, insurance of export-import supplies under state guarantee and activities of insurance intermediaries. The state guarantees the observance and protection of property and other rights and legitimate interests of insurers, conditions of free competition in the implementation of insurance activities. The main branches of the state insurance system are regional government insurance and inspection.

State supervision and regulation of companies in the field of life insurance is carried out in the following areas (Zalietov, 2006, $p$. 274):

1. Direct participation of the state in the development of a system of protection of property interests, which are conditioned by the necessity:

- provision of guarantees of social protection for certain categories of the population;

- providing guarantees to financial resources of insurers placed in the form of government securities;

- creation of target reserves that offset the insolvency of individual insurers in the performance of their obligations under life insurance contracts.

2. Legislative support for the formation and protection of the national life insurance market, which is complex and can be distinguished as a separate comprehensive branch of legislation, which includes regulatory acts that regulate the market.

3. State supervision, which is carried out in order to comply with the requirements of Ukrainian legislation on insurance, effective development of life insurance services, protection of rights and interests of insured, insured, heirs, insurers, insurance intermediaries, other interested parties and the state.

4. Protection of fair competition in the life insurance market, prevention and cessation of monopoly.

The state form of insurance expresses the relationship between the state insurance organization and the insured. It can be carried out in conditions of absolute state monopoly for carrying out all types of insurance, state monopoly on its separate types or in the absence of any state insurance monopoly. At the present stage, there is a tendency to develop the last option in Ukraine, although, of course, it does not rule out the priority of the state in carrying out certain types of compulsory insurance ( $\mathrm{Za}$ ruba, 1995, p. 28). Intervention in the activities of insurers by state and other bodies is prohibited, except for the rights of authorized bodies that exercise state supervision and control over the activities of insurers.

In accordance with Article 2 of the Law of Ukraine "On Insurance", life insurance companies may be created in the organizational and legal form of a joint-stock company, a full, limited partnership or an additional liability company. At that, the insurer's participants must be at least three. For this, the insurer is registered with the local executive body and entered in the Unified State Register of Financial Institutions.

About 80 insurance companies, both domestic and foreign, are engaged in life insurance in Ukraine. In the sphere of life insurance, 
it is possible to allocate six essential players, each of which in half a year receives more than 10 million UAH insurance premiums. This is Grave Ukraine, ALICO Ukraine, Garant Life, Blue Police, TAS and ASKA Life (Zaruba, 1995).

In accordance with the Laws of Ukraine "On Insurance", "On Financial Services and State Regulation of Financial Services Markets" and other laws, as well as the Regulation on the State Commission for the Regulation of Financial Services Markets of Ukraine, approved by the Decree of the President of Ukraine no. 292 of 04.04.2003. In order to ensure protection of the interests of consumers of financial services, to regulate the order of application of measures of influence and to ensure the protection of the rights of persons to whom they are applied, the Financial Services Commission has also established the procedure for the application of measures of influence on Finances institutions. Thus, the Regulation on the application by the State Commission for the Regulation of Financial Services Markets of Ukraine of measures of influence approved by the Regulation of the Financial Services Commission of Ukraine no. 2384 dated September 17, 2004 (registered with the Ministry of Justice of Ukraine on October 13, 2004 under no. 1310/9909) determines the procedure, terms and conditions of implementation in cases of violations of laws and other regulatory acts regulating the provision of financial services, including life insurance, the procedure for making decisions on the application of measures of influence and the procedure for their appeal.

Since such a Regulation regulates only the specific features of bringing administrative liability for violations related to activities in financial services markets, the Financial Services Commission selects and applies measures of influence on the basis of the analysis of data and information on violations of the legislation on financial services, taking into account the consequences of violations and consequences of previously applied measures of influence, if any.

\section{Conclusions.}

A detailed review of the "Insurance" legislation has given us the opportunity to conclude that, despite important changes and improvements, there are many unresolved issues regarding the organization of life insurance in Ukraine, namely:

- association of life insurance with other types of insurance (medical and pension) - as a consequence of increasing the insurer's sources of income, financial provision of insurance indemnity insurance;

- formation of the statutory fund of the insurer - the minimum statutory fund of the insurer, determined by law, in our opinion, should increase in line with the growth of insurance premiums in the company for the purpose of their additional security;

- introduction of tax privileges for insured persons (insured) under the programs of short-term life insurance;

- reinsurance of the insurer in the companies-insurers according to the investment grade uaAAA of the National Rating Scale;

- pension provision through long-term life insurance based on the second level of pension provision;

- expansion of directions of investment and credit activity of the insurance company.

The legislation on life insurance pays much attention to the organizational aspect of the establishment and operation of insurers, however, the implementation of the terms of the law can not reflect the state and reliability of the life insurance company, but does not affect the choice of the company in which the person wants to insure life. Therefore, there is an objective need to find out the theoretical and methodological foundations of the activities of such companies for making decisions on life insurance. 


\section{References}

Accounting Chamber of Ukraine (2004), "On the results of the inspection of the repayment of debts for impaired premiums of citizens of Ukraine placed before January 2, 1992 at the institutions of the former social insurance”, Postanova Kolehii Rakhunkovoi Palaty, no. 6-2, art. 9.

Alexandrova, M. M. (2002), Strakhuvannia [The Insurance], TsUL, Kyiv, Ukraine, 208 p.

Burling, J. (2017), “The Potential Effect of Brexit on Insurance Regulation in the UK”, Insurance Regulation in the European Union, pp. 79-106, doi: https://doi.org/10.1007/978-3-319-61216-4 5.

Cabinet of Ministers of Ukraine (2007), Resolution of the Cabinet of Ministers of Ukraine "On Approval of the National Rating Scale”, available at: http://zakon.rada.gov.ua/laws/show/665-2007 (Accessed 5 September 2018).

Cappiello, A (2018), Technology and the insurance industry: Re-configuring the competitive landscape, Springer International Publishing AG, Switzerland, 119 p., doi: https://doi.org/10.1007/978-3-319-74712-5.

Chvertko, L.A. and Demchenko, T.A. (2018), "Insurance tourist risks: The Problems of Theory and Practice", Economies’ Horizons, no. 1(4), pp. 67-75, doi: https://doi.org/10.31499/2616-5236.1(4).2018.132249.

Dilendorf, R. (2017), “Zarabotat y sokhranyt”, Zakhyst, vol. 345, pp. 1-51.

Dominique-Ferreira, S. (2017), "How important is the strategic order of product attribute presentation in the nonlife insurance market?”, Journal of Retailing and Consumer Services, vol. 34, January, 2017, pp. 138-144.

Dubyna, M. (2014), "Role of insurance agents in providing the growth of client's trust to the insurers", Finansovi resursy: problemy formuvannia ta vykorystannia universytetu. Visnyk Chernihivskoho derzhavnoho tekhnolohichnoho universytetu, no 2 (74), pp. 163-172.

Forte, P. E. (2017), “The American Long Term Care Insurance Program: A Solution to Reduce Cost and Provide Stability", American Society on Aging, vol. 40, no. 4, pp. 45-49.

Get Help Now “Rating Agencies-such As Standard \& Poor's” (S\&P), available at: http://www.chegg.com/homework-help/questions-and-nswers/rating-agencies-standard-poor-s-s-p-moody-s-investor-service-fitch-ratings-assign-credit-r-q11190539 (Accessed 5 September 2018).

Korol, I. V. (2018), Marketynhovi komunikatsii [Marketing communications], VPTs Vizavi, Uman, Ukraine, $250 \mathrm{p}$.

Kunreuther, H., Pauly, M. and McMorrow, S. (2013), Insurance \& behavioral economics. Improving decisions in the most misunderstood industry, Cambridge University Press, USA, $320 \mathrm{p}$.

Larsson, M. and Lönnborg, M. (2015). “The Survival and Success of wedish Mutual Insurers”, In: Pearson, R. and Yoneyama, T. (eds.). Corporate Forms and Organisational Choice in International Insurance, Oxford University Press, Oxford, pp. 93-113.

Louw, L. B. (2018), "Retrenchment in the insurance industry: the small business development dividend", Abstract of Ph.D. dissertation, Business Management, University of South Africa, Pretoria, South African Republic, available at: http://hdl.handle.net/10500/23898 (Accessed 5 September 2018).

Marano, P. (2016), “The 'Mifidization': The sunset of life insurance in the EU regulation on insurance?”, Liber Amicorum for Professor Ioannis Rokas, available at: https://ssrn.com/abstract=2832952 (Accessed 5 September 2018).

Marshall, A. (1993), Principy jekonomicheskoj nauki [Principles of Economic Science], IG Progress, Moscow, Russia, 250 p.

Martsenishyn, D. (2005), "Strakhuvannia zhyttia: borotba za vtracheni pozytsii”, Pensiinyi kurier. no. 9, pp. 5-8.

Melnychuk, Yu. M. (2018), Teoriia i praktyka strakhuvannia zhyttia v Ukraini [Theory and Practice of Life Insurance in Ukraine], VPTs Visavi, Uman, Ukraine, 158 p.

Melnychuk, Yu. M. and Garmatiuk, O. V. (2018), "Factors of influence on sales activities of insurers of life insurance”, Economies' Horizons, no. 1(4), pp.60-66, doi: https://doi.org/10.31499/26165236.1(4).2018.132246.

Official site of insurance companies rating (2018), available at: https://forinsurer.com/ratings /life/18/6/4 (Accessed 5 September 2018).

Osipov, V.E. (1999), Ceny i cenoobrazovanie [Price and Pricing], Piter, St. Petersburg, Russia, 464 p.

Petru, D., Vilijencova, N. and Daian, D. (2018), "Insurance Accounting in Romania", Economics World, vol. 6, no. 3, pp. 242-247.

Podolak, G. D. (2015), "Insurance for Cyber Risks: A Comprehensive Analysis of the Evolving Exposure”, Today's Litigation and Tomorrow's Challenges, vol. 33, pp. 369-371, available at: http://apps.americanbar.org/litigation/committees/insurance/articles/marchapril2014-cyber-risk-litiga-tion.html (Accessed 5 September 2018). 
Porrini, D. (2017), “Regulating Big Data effects in the European insurance market”, Insurance Markets and Companies, vol. 8(1), pp. 6-15.

Ratna, V. (2005), “Pohlynai i volodariui”, Halytski kontrakty, no. 1-2, pp. 3-8.

Reznichenko, K. H. and Samofat, I. S. (2015), "Features of taxation of insurance companies in Ukraine” Zbirnyk naukovykh prats Natsionalnoho universytetu derzhavnoi podatkovoi sluzhby Ukrainy, no. 1, p. 144.

Sangowskiego, T. (2001), Ubezpieczenia gospodarcze [Economic insurance], Poltext, Warszawa, Polish, 390 p.

Shauhin, T. (2017), Data Breach, Privacy, and Cyber Insurance: How Insurance Companies Act as "Compliance Managers" for Businesses, L. \& SOC. INQUIRY, pp. 162-175.

Sholoiko, A. (2017), "European vector of development of non-insurance intermediaries in Ukraine", Visnik Kiïvskogo Nacìnal'nogo Unìversitetu ìmenì Tarasa Ševčenka. Ekonomìka, vol. 5, no. 194, pp. 66-71.

Stewart, A. E. (2015), Insurance Law Update, 70 AD-VOC. (TEX.), pp. 248, 257-258.

The Verkhovna Rada of Ukraine (1996), The Law of Ukraine "On Insurance", Vidomosti Verkhovnoi Rady Ukrainy, no. 18, p. 78.

The Verkhovna Rada of Ukraine (2001), The Law of Ukraine "On Insurance", available at: http://www.kmu.gov.ua, (Accessed 5 September 2018).

The Verkhovna Rada of Ukraine (2002), The Law of Ukraine "On Financial Services and State Regulation of Financial Services Markets”, Vidomosti Verkhovnoi Rady Ukrainy, no. 1, p. 1.

The Verkhovna Rada of Ukraine (2005), The Law of Ukraine "On Amendments to the Law of Ukraine "On Insurance", available at: http://www.kmu.gov.ua (Accessed 5 September 2018)

Tkachenko, A. M. and Shmatko, K. A. (2013), "The Mediation on the market of insurance services of Ukraine”, Poserednytstvo na rynku strakhovykh posluh Ukrainy, vol. 1, no. 2, pp. 130-132.

Vuuren, V. and Justine, A. (2017), "Historical analysis of the origins, development and nature of market conduct regulation: a study of four insurance markets", available at: http://www.wiredspace.wits.ac.za (Accessed 5 September 2017).

Yaremenko, N. V. (2013), “Insurance agent: the essence and main functions”, Visnyk ZhDTU, no. 1 (63), pp. 378379.

Zadorozhnyi, S. V. and Yushchenko, A. S. (2014), "Current problems of the institute of insurance mediation”, Molodyi vchenyi, no. 1 (03), pp. 71-74.

Zalietov, O. M. (2006), Ubezpechennia zhyttia [The Insurance life], Mizhnarodna ahentsiia "BIZON”, Kyiv, Ukraine, $688 \mathrm{p}$.

Zanghieri, P. (2017), "Business cycle and motor insurance profitability: evidence for Italy", available at: https://ssrn.com/abstract=3084554, doi: http://dx.doi.org/10.2139/ssrn.3084554 (Accessed 5 September 2018).

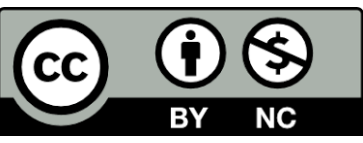

Цей твір ліцензовано на умовах Ліцензії Creative Commons «Із Зазначенням Авторства - Некомериійна 4.0 Міжнародна» (CC BY-NC 4.0). This is an open access journal and all published articles are licensed under a Creative Commons "Attribution-NonCommercial 4.0 International" (CC BY-NC 4.0). 